\title{
CONTRIBUTION OF FORESTRY SUBSECTOR TO ECONOMIC DEVELOPMENT OF KOTAWARINGIN BARAT REGENCY
}

\author{
Jumri, Sari Mayawati \\ Lecturers of Agricultural Faculty, Forestry Department \\ Palangka Raya University, Palangka Raya, Central Kalimantan, Indonesia
}

Email: mayajumri@yahoo.co.id

\begin{abstract}
Forest as the financial capital for development has important roles in economic development of Kotawaringin Barat Regency. Commonly, forest is a large area of land where flora (trees) and fauna (animals) exist. It can produce woods and other products for human consumption (production function), regulate the water system for human life, prevent flooding and sea water intrusion (protection function), and preserve many species of plants and animals and ecosystem (conservation function). Economically, forest as the source of woods, rattans and other products provided foreign exchange for the country during 1980-1990; this case placed the subsector of forestry as one of the prime movers in Indonesia's economy. The purpose of this research was to analyze the extent of the foresty's contribution to the economic development and social welfare in Kotawaringin Barat Regency. The research methodology was conducted by: a) interview, b) observation / field surveys and c) documentation (supporting data). The results showed that the contribution of forestry subsector in the economic development and social welfare of Kotawaringin Barat reached IDR 38.6 billion in 2011.
\end{abstract}

Keywords: Contribution, Economy, Welfare

\section{INTRODUCTION}

The aproximate 1.2 million hectares of forests in Kotawaringin Barat Regency have contributed to national revenue since 1970 in the context of national development. The economic development in Kotawaringin Barat can not be separated from the forestry because this subsector both directly and indirectly gives benefits to the value of regional gross domestic product (GDP). The direct benefits can be economically gained from the timber and non-timber's production. Indirectly, the forest provides fields in business and job opportunities. The small contribution of the forestry subsector to the acquisition value of GDP is due to a lot of value gains derived from this field are not included in the GDP. Those values, such as from the forestry processing industry sector and non-timber forest products (rattan, jelutung, resin etc.), should be taken into account.

Association of Indonesian Forest Concessionaires (2004) states that timber as the product of forest so called "green gold" has become the second largest contributor to the foreign exchange after oil and gas. How optimal the contribution of Indonesia's forestry subsector could be seen from foreign exchange contribution up to US\$ 7-8 billion per year before the financial crisis in 1997 as well as state income in the form of tax and non-tax and job vacancies. In real implementation, there are 15 types of taxes and non-taxes for every cubic meters of timber harvested from this subsector. The economic magnitude interest of timber in the form of tax and non tax entirely ranges between $30-45 \%$ of each cubic meter (APHI, 2004), including 1) the contribution of forestery concessions 2) provision of forest resources 3 ) reforestation funds 4 ) property taxes (earth and building) 5) contribution of forest development community 6) boundary contribution 7) vehicle tax 8) motor vehicle ownership transfer fee 9) corporate income tax / agency income tax 10) value added tax / VAT and 11) Employment insurance fund.

The Development of Indonesian Forestry juridically should refer to the Regulation of the Republic of Indonesia Number 41 Year 1999 on Forestry. The law as the main reference in forestry management has the purposes of guaranteeing the forest existence, maximizing various functions of forests and supporting a fair and sustainable distribution of benefits. Therefore, all rules under it must not conflict the existing law. Such harmonization can assist the implementation of sustainable forest management which is economically and ecologicaly guaranteed. 
The role of forest resources is absolutely necessary in the context of Indonesian economic development. Therefore, forest as timber or non-timber needs to be preserved so that the sustainability of these resources can actively contribute to Indonesian economic development. Forest as the timber producer offers two options when it is exploited continuously to optimize the economic growth. It will be a source of great income for the country, on the other hand, it will be a serious treat for environment. In order to overcome these problems, a balance between the number of forest products and the growth of the forest itself is needed. The objective of this research is to analyze the extent of the contribution of forestry subsector to the economic development and social welfare of Kotawaringin Barat Regency.

\section{MATERIALS AND METHODS}

This study was conducted in Kotawaringin Barat Regency, Central Kalimantan Province. This research was conducted by: a) interview, b) observation/field surveys and c) documentation (supporting data). The primary data were obtained from the companies in the field of forestry subsector (IUPHHKHA), while the secondary data were obtained from the local Central Statistics Agency. Data analysis tool used was a calculation of the value of reforestation fund (RF) plus the value of forest resource provision $(\mathrm{PSDH})$ to the total production of logs produced by the companies in 2011. The details are as follows:

The contribution of forestry subsector in the form of RF and PSDH = [ $\{R F$ value $=$ total log production $x$ value of $R F / \mathrm{m}^{3}$ logs (16.US. \$) $\}+\{$ PSDH value $=$ total $\log$ production $\times 10 \%$ of the reference price for $\log \}]$. In this case:

a) Contribution of forestry subsector is the involvement of forest resource (wood) as the role in regional gross domestic product so that the impact can be judged from the social and economic aspects.

b) RF is a forestry contribution that needs to be paid by the timber companies to the government by $16 \mathrm{US} \$ / \mathrm{m}^{3}$ logs based on the log production.

c) PSDH is a forestry contribution needs to be paid by the timber companies based on log production. The amount of contribution is $10 \%$ of the reference price for Indonesian forestry log as set in the Regulation of Ministry of Trade No. 22 / M-DAG-4/2012, 24 April 2012.

\section{RESULTS AND DISCUSSION}

Based on the results of research, the data of log production in 2011 are presented in Table 1, which showed the contribution of forestry subsector to the economic development from the log production was $175,682.90 \mathrm{~m}^{3}$. After calculated with a formula encapsulated in the data analysis, the contribution of this subsector reached IDR 38.6 billion in 2011.

Tabel 1. Log Production from Kotawaringin Barat Regency in 2011

\begin{tabular}{lrl}
\multicolumn{1}{c}{ Company } & Volume $\left(\mathrm{m}^{3}\right)$ & \multicolumn{1}{c}{ Resource } \\
\hline PT. Erythina Nugraha Megah & $28,204.16$ & $\begin{array}{l}\text { Department of Forestry Level 1, Central } \\
\text { Kalimantan } \\
\text { PT. Central Kalimantan }\end{array}$ \\
\hline PT. Intrado Jaya Intiga & $6,170.40$ & Company \\
\hline PT. Karda Traders & $5,021.03$ & Company \\
\hline PT. Hutanindo Lestari Raya Timber & $87,507.56$ & Company \\
\hline Total & $175,682.90$ & - \\
\hline Source: Research results in 2012 & &
\end{tabular}

The contribution of forestry subsector mentioned above, year by year tended to decrease by $0.27 \%$, which means that the forests in Kotawaringin Barat Regency need to be settled in specific ways so that the forest products can increase the value of regional gross domestic product (GDP). The specific settlement can be done by setting the number of production every year including the area of logging and log volume that should be no more than the growth level. It is necessary to maintain the balance between the forest growth and the forest production. Thus, the contribution of forest resources can increase the GDP and provide social welfare to society. The increase in the contribution of forestry subsector to Kotawaringin Barat will directly affect to economic development in a positive way. Therefore, the forests in Kotawaringin Barat 
need to be well preserved based on the forest treatment principles in the Regulation No. 41 Year 1999 on forestry.

The decrease in forestry contribution is caused by reduction of forest area for producing timber in Kotawaringin Barat and the deforestation done by irresponsible people. The vast forest areas highly influence the timber production. Because of this case, in order to maintain the stability of timber production in Kotawaringin Barat Regency, the law supremacy needs to be enforced for those who are doing deforestation. Law is the commander in law enforcement to catch the forest criminals; it is absolutely needed to protect the forest from irresponsible people. On the other hand, the policy to redirect the forest's functions to other sectors should be reconsidered in order to keep the forest running its function in production, protection and conservation.

\section{CONCLUSIONS}

It can be concluded that in 2011 the total log production by the forest concessionaires in Kotawaringin Barat Regency was $175,682.90 \mathrm{~m}^{3}$. The value of the contribution of forestry subsector to the economic development in Kotawaringin Barat Regency reached IDR 38.6 billion in 2011.

It is recommended that in order to achieve both the conservation of forest resources and the increase in forest products, all the activities in the forest management should be fully carried out based on the Forestry Regulation No. 41 Year 1999 on Forestry. The calculation between the recent values of contribution (RF and PSDH) of Indonesia's forest logs need to be reconsidered because the net value of trees (forest stands) of Indonesia nature is much greater if calculated using an economic rent approach than the value of RF and PSDH by IDR 520,330 per $\mathrm{m}^{3}$ log. The government needs to carry out the reforestation the open lands by making its own installation (KPH Lestari) in order to reduce the forest destruction and to create the sustainable forest formation.

\section{REFERENCES}

State Secretariat of the Republic of Indonesia (1999). The Regulation of the Republic of Indonesia Number 41 Year 1999, 30 September 1999 on Forestry. Jakarta.
PT. Hutanindo Lestari Raya (2012). Corporate Work Plan 2011.

PT. Intardo Jaya Intiga (2012). Corporate Work Plan 2011.

PT. KardaTraders (2012). Corporate Work Plan 2011. 